\title{
Efficient use of Dimilin insecticide in forestry of the region
}

\author{
Lyudmila Zhichkina ${ }^{1,}$, , Vladimir Nosov ${ }^{2,3}$, Kirill Zhichkin ${ }^{1}$, Aleksandr Nayanov $^{4}$, \\ Natalya Vertiy $^{2}$ and Arina Eroshenko ${ }^{2}$ \\ ${ }^{1}$ Samara State Agrarian University, 446442 Kinel, Russian Federation \\ ${ }^{2}$ K.G. Razumovsky Moscow State University of Technologies and Management, 109004 Moscow, \\ Russian Federation \\ ${ }^{3}$ Academy of the Investigative Committee of the Russian Federation, 125080 Moscow, Russian \\ Federation \\ ${ }^{4}$ Saratov State Vavilov Agrarian University, 410012 Saratov, Russian Federation
}

\begin{abstract}
Insects have a strong influence on the state of forests. Damage by pests often results in negative changes in the forest ecosystem. The benzoylphenylurea insecticide Dimilin is widely used in agriculture and forestry to control pests. The purpose of the study is to estimate possible forest damage from Acantholyda posticalis and to analyze the effectiveness of the Dimilin insecticide. The paper provides the following description of possible damage from Acantholyda posticalis: with the extent of damage to crowns of $74 \%$, the blight of pines will be $9 \%$; with the predicted crown damage from tree browsers the potential loss of pine tree recruitment will be $93 \%$; shrinkage of forest stands by $0.09 \%$ will result in the loss of water protection properties of forests amounting to 5.33 thousand EUR; the loss of water regulation functions will amount to 2.13 million EUR.
\end{abstract}

\section{Introduction}

The forest fund of the Samara region has a status of a protection forest. However, in forestry we do not always assess the reduction in protective properties due to the impact of pests. Acantholyda posticalis (Hymenoptera, Pamphiilidae) is a widely spread pine pest [13]. Pest population outbreaks occur in the undergrowth, mature and overmature forests. The breeding ground often covers large areas in the European part of Russia, Southern Transurals, south of West Siberia, Altai and Transbaikal [4-6].

Acantholyda posticalis significantly influences the stand conditions: it can decrease the resistance of forest stands to secondary pests and diseases, reduce recruitment of trees, lessen the recreational appeal of forests and affect water protection and regulation functions of the forest [7-10].

The forest fund of the Samara region faces challenges associated with large areas of a breeding ground for needle-eating insects that threaten the pine stands. This results from the weather conditions favorable to insect outbreaks and a small number of pest control

* Corresponding author: zskirill@mail.ru 
activities undertaken in 2018. Pests suppression and eradication activities should be undertaken to prevent damage to forest stands.

The study of insect population dynamics is an integral part of environmental measures to protect forest stands from the impact of population outbreaks of needle-eating insects [11-15]. Insects have a strong influence on the state of forests. Damage by pests often results in negative changes in the forest ecosystem. Mass reproduction of pests causes total or partial instability of biopersistence of forest stands, loss of tree recruitment and other adverse consequences [16-18].

To identify the patterns and determine their development in the Samara region, we need to conduct a deep and detailed study of climate and weather conditions, sanitary state of forests, stages of establishment of homogeneous forest stands and pest control measures [19-21].

\section{Methodology}

Changes in pests population and level of population are inferred from population density (average or absolute colonization), reproductive rate, infection of pests with entomophages and diseases, the internal state of the organism (fertility, pupas, number of eggs in batches, etc.). Places where the population of insects grows usually become a breeding ground for pests. The breeding ground is a forest plot populated by pests, where their number threatens the forest stands with the loss of more than $30 \%$ of needles (or more than $50 \%$ of leaves). In such cases there is a need for pests suppression and eradication activities.

Measures to contain and eradicate pest harborage areas include forest care activities with the use of special equipment and methods of treatment (land-based and aerial) with chemical and biological products.

\section{Results and Discussion}

Preservative treatments in harborage areas of Acantholyda posticalis were first applied in the middle of the XX century. If pyrethroid insecticides are only applied once they cannot provide effective pest control because not all of the individuals are affected by the product. Early treatment is also not effective, as some adults are still in the process of egg-laying, and if treated too late, some of the larvae would have finished feeding and burrowed into the soil.

However, practical experience shows that it is problematic to obtain reliable results of preservative treatments against Acantholyda posticalis. The most appropriate method of needle leaf trees protection is single treatments with the Dimilin insecticide - dry powder, $250 \mathrm{~g} / \mathrm{kg}$ of the active ingredient. Treatment should be applied when adult insects are still flying and most pests in the forest stands are still in the process of egg-laying or are in the larvae stage. When the Dimilin insecticide contacts with leaves, it coats them and almost does not wash away with the rain. The metabolism of the insecticide is rather slow, and its relative amount applied on leaves decreases mostly because the plants grow. Described characteristics of the product, as well as its high resistance to sunlight and temperature, predetermine the length of the protection period of the insecticide, which is at least 3-4 weeks. In soil, the half-life of Dimilin is ranging from 2 to 7 days, in water, its half-life is about 24 hours, unlike most organophosphorus pesticides (about a month) and pyrethroids (from 17-29 days to 13 weeks) [22, 23].

The calculations of costs of Acantholyda posticalis eradication and suppression activities in the Stavropol forest stands, presented in table 1, show that the highest costs were for the rent of units - 357.4 thousand RUB (49\%) and purchase and delivery of the 
product - 339.29 thousand RUB (47\%). Other costs, such as the price of the insecticide diluent, spring control examinations of pests harborage areas, estimation of efficiency and activities on the restriction of individuals' presence in forests, were no more than $4 \%$ [24].

Table 1. Estimated costs of activities on Acantholyda posticalis eradication and suppression in Stavropol forest stands.

\begin{tabular}{|c|c|c|c|c|}
\hline Costs & Unit & Volume & Total cost, EUR & Costs, EUR /ha \\
\hline Units rent & $\mathrm{Ha}$ & 755.6 & 4306.01 & 5.70 \\
\hline $\begin{array}{c}\text { Purchase and delivery of the } \\
\text { product }\end{array}$ & $\mathrm{Kg}$ & 66.49 & 4087.87 & 5.41 \\
\hline $\begin{array}{c}\text { Cost of diluent for the } \\
\text { insecticide }\end{array}$ & $\mathrm{L}$ & 2426.9 & 0.76 & 0.001 \\
\hline Total & & 7 & 8394.64 & 11.11 \\
\hline $\begin{array}{c}\text { Spring control examinations of } \\
\text { pests harborage areas }\end{array}$ & Control points & 7 & 46.73 & 0.02 \\
\hline Estimation of effectiveness & Control points & & 239.05 & 0.06 \\
\hline $\begin{array}{c}\text { Activities on the restriction of } \\
\text { individuals' presence in forests }\end{array}$ & EUR & & 178.92 & 0.32 \\
\hline Including equipment costs & & & 302.08 & 0.24 \\
\hline Total & & & 8696.71 & 11.51 \\
\hline Overall & & & \\
\hline
\end{tabular}

The cost of $1 \mathrm{~kg}$ of the insecticide was described as the lowest based on three price lists. The three major suppliers of the product are OOO 'Company Agroprogess' (Krasnodar, Krasnodar Krai) - the price of the product is 62.81 EUR $/ \mathrm{kg}$, OOO "HimAgro Group" (Krasnodar, Krasnodar Krai) - 61.48 EUR/kg and 'Agroprogress' (Saint-Petersburg) - 61.48 $\mathrm{EUR} / \mathrm{kg}$.

To obtain the desired results with least amount of money, we chose the insecticide supplied by OOO "HimAgro Group" (Krasnodar, Krasnodar Krai) based on the value for money principle, as this supplier offers the insecticide at the lowest price (61.48 EUR). The amount of required insecticide is $66.49 \mathrm{~kg}$. In accordance with table 2, the total cost of the product is 4.09 thousand EUR for the workload of 755.6 ha, provided that treatments are applied with a $10 \%$ overlap and the application rate is $0.08 \mathrm{l} / \mathrm{ha}$.

Table 2. Price of the Dimilin dry powder and the diluent (water) used to prepare the insecticide for treatment.

\begin{tabular}{|c|c|c|c|c|c|}
\hline $\begin{array}{c}\text { Treated } \\
\text { area, ha }\end{array}$ & $\begin{array}{c}\text { Area treated } \\
\text { with a 10\% } \\
\text { overlap, ha }\end{array}$ & $\begin{array}{c}\text { Application rate } \\
\text { of the insecticide } \\
\text { or diluent, 1/ha }\end{array}$ & $\begin{array}{c}\text { The amount of } \\
\text { required } \\
\text { insecticide or } \\
\text { diluent, 1/kg }\end{array}$ & $\begin{array}{c}\text { Price of the } \\
\text { insecticide or } \\
\text { diluent per 1 1/kg }\end{array}$ & $\begin{array}{c}\text { Total cost of } \\
\text { the insecticide } \\
\text { or diluent, } \\
\text { EUR }\end{array}$ \\
\hline \multicolumn{7}{|c|}{ The Dimilin dry powder } \\
\hline 755.6 & 831.16 & 0.08 & 66.49 & 61.48 & 4087.87 \\
\hline 755.6 & 831.16 & 2.92 & 2426.9 & 0.001 & 0.76 \\
\hline
\end{tabular}

According to table 2, rate of water per 3 litres of the insecticide is 2.92 litres (per 1 ha of the harborage area), rate of water per total amount considering the $10 \%$ overlap is 2426.99 litres. 
Table 3 shows that the cost of renting the Gard unit was 4.3 thousand EUR for the total workload of 831.16 ha considering the $10 \%$ overlap.

Table 3. The costs of renting the ground unit for the treatment.

\begin{tabular}{|c|c|c|c|c|c|}
\hline Works & $\begin{array}{c}\text { The name of } \\
\text { the unit }\end{array}$ & Area, ha & $\begin{array}{c}\text { Area considering } \\
\text { a 10\% overlap }\end{array}$ & $\begin{array}{c}\text { Cost of renting, } \\
\text { EUR/ha }\end{array}$ & $\begin{array}{c}\text { Total cost of } \\
\text { renting, EUR }\end{array}$ \\
\hline $\begin{array}{c}\text { Treatment of } \\
\text { forest stands }\end{array}$ & Gard & 755.6 & 831.16 & 5.18 & 4306.00 \\
\hline $\begin{array}{c}\text { Workers } \\
\text { transporting }\end{array}$ & \multicolumn{5}{|c|}{ Included in the rent } \\
\hline Driving the unit & & & 831.16 & 5.18 & 4306.00 \\
\hline & Total & 755.6 & &
\end{tabular}

Table 4 shows calculations of costs of the Stavropol forest district of the state public institution 'Samara forest districts' of the Samara Ministry of forestry, environment and nature of the activities on the restriction of individuals' presence in forests during pests suppression and eradication activities.

One newspaper advertisement for the activities on restriction of individuals' presence in forests during pests suppression and eradication activities costs 12.05 EUR. Two advertisements are needed, therefore, their total cost is 24.1 EUR. The cost of information signs is $19.88 \mathrm{EUR} /$ piece, 9 signs are required.

Leaflets on the restriction of individuals' presence in forests during pests suppression and eradication activities cost 21.69 EUR, 150 leaflets are required.

Table 4. Costs of the activities on the restriction of individuals' presence in forests during pests suppression and eradication activities in the Stavropol forest district in 2018.

\begin{tabular}{|c|c|c|c|}
\hline Types of work & Workload & Date & $\begin{array}{l}\text { Amount of } \\
\text { money, EUR }\end{array}$ \\
\hline Advertisements in the newspapers & 2 & $\begin{array}{c}\text { The } 1^{\text {st }} \\
\text { decade of } \\
\text { April }\end{array}$ & 24,10 \\
\hline Leaflets & 150 & & 21,69 \\
\hline Sign making, placement and removal, including: & 9 & $\begin{array}{c}\text { The } 2^{\text {nd }} \text { and } \\
3^{\mathrm{d}} \text { decades } \\
\text { of April }\end{array}$ & 178,92 \\
\hline Salary & $\begin{array}{c}2 \text { man } \\
\text { days }\end{array}$ & & 12,12 \\
\hline $\begin{array}{l}\text { Cost of petroleum, oil and lubricants (Lada Niva): } \\
\text { Highway }-12.3 \text { per } 100 \mathrm{~km} \text { (price per liter }-0.42\end{array}$ & 160 & & 8.33 \\
\hline $\begin{array}{l}\text { EUR); } \\
\text { Off-road - } 14.2 \text { per } 100 \mathrm{~km} \text { (price per liter - } 0.42 \text { EUR) }\end{array}$ & 100 & & 6.01 \\
\hline Consumable materials & \multicolumn{3}{|c|}{ Included in the cost of sign making } \\
\hline Total & & & 239.05 \\
\hline
\end{tabular}

Salaries of workers involved in the activities on the restriction of individuals' presence in forests during pests suppression and eradication activities are 12.12 EUR.

Costs of petroleum, oil and lubricants for Lada Niva (the necessary mileage of $260 \mathrm{~km}$ ) are 14.34 EUR. 
The total cost of the activities on the restriction of individuals' presence in forests during pests suppression and eradication activities in the Stavropol forest district is 8.7 thousand EUR, at a cost of $11.50 \mathrm{EUR} / \mathrm{ha}$. Costs of groundworks amount to 8.39 thousand EUR, at the cost of $11.11 \mathrm{EUR} / \mathrm{ha}$.

Table 5 shows the costs of the activities on the restriction of individuals' presence in forests during Acantholyda posticalis suppression and eradication activities and costs of estimation of technical efficiency of the Stavropol forest district treatment.

Table 5. Costs of control examination of harborage areas and estimation of technical efficiency of the Stavropol forest district treatment in 2018.

\begin{tabular}{|c|c|c|c|}
\hline Types of work & Workload & Date & $\begin{array}{r}\text { Amount of } \\
\text { money, EUR }\end{array}$ \\
\hline $\begin{array}{l}\text { Control examination of harborage areas, } \\
\text { including: }\end{array}$ & 755.6 ha (7 units) & $\begin{array}{l}\text { The } 1^{\text {st }} \text { decade of } \\
\text { April }\end{array}$ & \\
\hline \multicolumn{4}{|l|}{ Salary, travel expenses, bonuses } \\
\hline $\begin{array}{l}\text { Cost of petroleum, oil and lubricants } \\
\text { (Lada Niva): }\end{array}$ & & & \\
\hline $\begin{array}{l}\text { Highway - } 12.3 \text { per } 100 \mathrm{~km} \text { (price per } \\
\text { liter - } 0.42 \text { EUR); }\end{array}$ & 160 & & 8.33 \\
\hline $\begin{array}{l}\text { Off-road - } 14.2 \text { per } 100 \mathrm{~km} \text { (price per } \\
\text { liter - } 0.42 \text { EUR) }\end{array}$ & 100 & & 6.01 \\
\hline Gloves, pcs & 2 & & 1,95 \\
\hline Total & & & 16,30 \\
\hline $\begin{array}{l}\text { Technical efficiency estimation (twice), } \\
\text { including: }\end{array}$ & 7 units & $\begin{array}{l}1 \text { day before } \\
\text { treatment, on the } \\
13^{\text {th }} \text { day after } \\
\text { treatment }\end{array}$ & \\
\hline \multicolumn{4}{|l|}{ Salary, travel expenses, bonuses } \\
\hline $\begin{array}{l}\text { Cost of petroleum, oil and lubricants } \\
\text { (Lada Niva): }\end{array}$ & & & \\
\hline $\begin{array}{l}\text { Highway - } 12.3 \text { per } 100 \mathrm{~km} \text { (price per } \\
\text { liter - } 0.42 \text { EUR); }\end{array}$ & $320 \mathrm{~km}$ & & 16.67 \\
\hline $\begin{array}{l}\text { Off-road - } 14.2 \text { per } 100 \mathrm{~km} \text { (price per } \\
\text { liter - } 0.42 \text { EUR) }\end{array}$ & $200 \mathrm{~km}$ & & 12.03 \\
\hline Consumable materials (canopy), pcs. & 1 & & 8,67 \\
\hline Respirators, pcs. & 7 & & 2,53 \\
\hline Gloves, pcs. & 7 & & 6,83 \\
\hline Total & & & 46,73 \\
\hline Total & & & 63,03 \\
\hline
\end{tabular}

The costs of control examinations of Acantholyda posticalis harborage areas and estimation of technical efficiency of the Stavropol forest district treatment amount to 63.03 EUR. Control examinations of harborage areas are scheduled on the $1^{\text {st }}$ decade of April. Technical efficiency is estimated twice: 1 day before treatment and on the $13^{\text {th }}$ day after treatment.

We conducted the estimation of technical efficiency of treatments in Acantholyda posticalis harborage areas in 17, 2, 7 divisions of the Fedorovsk forest district and in 9, 13, 31, 59 divisions of the Musorsk forest district on the area of 64.8 ha. 
Estimations were conducted on 7 units 1 day before treatment and on the $13^{\text {th }}$ day after treatment. To conduct these estimations, we used the paired-tree method.

The specific feature of this method is that only living larvae are estimated before and after the treatment. The method does not include the estimation of dead larvae. Every estimation unit consists of two trees of the same species growing near each other. Trees of one unit should be similar in the crown development and pest colonization. On one of the trees in pair, larvae are estimated before the treatment and on the other one - approximately after 5-6 days after the treatment. To determine the number of larvae, trees and their crowns are cut onto the entomological canopy or a cleared area. Different quantities of larvae on both trees are taken as the number of dead insects.

The results show that egg batches and caterpillars were treated with the Dimilin dry powder using the ground chemical method within the period from 7 June to 11 June 2018 . Table 6 provides data on technical efficiency of measures to contain and eradicate Acantholyda posticalis harborage areas in Stavropol forests in 2018.

Table 6. Technical efficiency of measures to contain and eradicate Acantholyda posticalis harborage areas in Stavropol forests in 2018.

\begin{tabular}{|c|c|c|c|c|}
\hline Number & $\begin{array}{c}\text { Number of larvae } \\
\text { before treatment, } \\
\text { spec. }\end{array}$ & $\begin{array}{c}\text { Number of larvae } \\
\text { before treatment, } \\
\text { spec. }\end{array}$ & $\begin{array}{c}\text { Technical } \\
\text { efficiency, \% }\end{array}$ & $\begin{array}{c}\text { Damaged forest } \\
\text { stands on treated } \\
\text { plots, \% }\end{array}$ \\
\hline Minimum & 4132 & 32 & 90.1 & 0.4 \\
\hline Maximum & 10219 & 824 & 99.6 & 9.9 \\
\hline $\begin{array}{c}\text { Average number } \\
\text { per working area }\end{array}$ & 7176 & 428 & 94.9 & 5.2 \\
\hline
\end{tabular}

Before these activities the minimum number of Acantholyda posticalis per tree was 4132 larvae, the maximum number was 10219 larvae, the average number per one tree was 7176 larvae.

After treatment with the Dimilin dry powder, the minimum number of Acantholyda posticalis was $32 \mathrm{spec} . /$ tree, the maximum number was $824 \mathrm{spec} . /$ tree and the average number per one tree was 428 spec.

Technical efficiency of measures to contain and eradicate pests harborage areas ranged from 90.1 to $99.6 \%$. The average percentage for all units was $94.9 \%$.

The minimum damage to forest stands after the described measures were undertaken was $0.4 \%$, the maximum damage was $9.9 \%$ and the average percentage was $5.2 \%$.

Hence, the activities on suppression and eradication of Acantholyda posticalis harborage areas in the Stavropol forest district have proven to be effective and have not severely damaged the pine stands. Damage to crowns caused by Acantholyda posticalis can result in the blight of pines, which can result in forest mortality. Crown damage caused by these needle-eating insects is $74 \%$, therefore, the blight of pines is $9 \%$. Possible losses from damage to forest stands can be expressed in the loss of pine trees recruitment and water protection properties of the forest.

The shift of forest reproduction cycle can be tracked through the calculation of the loss of pine recruitment caused by damage to tree crowns. Provided that the potential damage from tree browsers is $74 \%$, the loss of pine recruitment will be $93 \%$. Water protection functions of the forest are based on the increase in the flow of underground sources due to surface waters. Damage from total or partial tree mortality is estimated based on the decrease in groundwater recharge with surface water. The loss of water protection properties of forests due to the $0.09 \%$ blight of the forest stand area amounts to 5.32 thousand EUR. Soil protection properties of forests include water regulation properties and express in an increase in flow, a decrease in salinization and contamination of water bodies 
and rivers with wastewater, drainage water and erosion. The loss of water regulation properties of the forest due to the $0.09 \%$ blight of the forest stand area amounts to 2130.12 thousand EUR. The absorptive properties of the forest lie in the absorption of polluting emissions from industrial facilities, transport, agricultural production. The surface of soil and plants is the main absorbent of pollutants from the underground ecosystems. Pests harborage areas amount to 755.6 ha. The average number of trees per 1 ha is 3430 . If we examine $1 \%$ of the area, we can see that the blight of $9 \%$ of these trees results in an economic loss of 28.1 thousand EUR. Unfortunately, because of the absence of norms, we cannot estimate the damage from the blight of forest stands, the loss of tree recruitment, the loss from possible water and wind erosion, and the reduction in recreational value.

Considering the weakened state of forest stands and predicted browsing of $74 \%$, we can safely assume that without measures to contain and eradicate harborage areas, biological stability will be reduced and a part of forest stands will die [25]. All of this in combination with economic losses confirms the need for ground measures to contain and eradicate Acantholyda posticalis harborage areas in the forest fund of the Stavropol region.

\section{Conclusion}

Within the research, we analyzed natural and climatic conditions of the forest district, recommended ground activities on the eradication of Acantholyda posticalis in forests of the Stavropol forest district. Harborage areas of Acantholyda posticalis in the Stavropol forest district amounted to 755.6 ha in 2018, including 390.1 ha of forest stands ( $52 \%$ of the harborage area) with the damage rate varying from 50 to $75 \%$. The total cost of pests suppression and eradication activities in the Stavropol forest district is 8.39 thousand EUR, at the cost of $11.11 \mathrm{EUR} / \mathrm{ha}$.

The results of eradication activities undertaken in 2018 show that the technical efficiency of the treatment ranged from $90.1 \%$ to $99.6 \%$ and the average percentage for all units was $94.9 \%$.

In 2018 after treatment with the Dimilin insecticide, the damage rate amounted to 0.4$9.9 \%$, the average percentage was $5.2 \%$.

The potential damage to forest stands from Acantholyda posticalis can be described as follows: with the extent of damage to crowns of $74 \%$, the blight of pines will be $9 \%$; with the predicted crown damage from tree browsers the potential loss of pine tree recruitment will be $93 \%$; shrinkage of forest stands by $0.09 \%$ will result in the loss of water protection properties of forests amounting to 5.33 thousand EUR; the loss of water regulation functions will amount to 2.13 million EUR.

\section{References}

1. L. Cayuela, J. A. Hódar, R. Zamora, Is insecticide spraying a viable and cost-efficient management practice to control pine processionary moth in Mediterranean woodlands? Forest, Ecology and Management, 261, 1732-1737 (2011) doi 10.1016/j.foreco.2011.01.022

2. E. Hyvärinen, J. Kouki, P. Martikainen, H. Lappalainen, Short-term effects of controlled burning and green-tree retention on beetle (Coleoptera) assemblages in managed boreal forests, Forest Ecology and Management, 212, 315-332 (2005) doi 10.1016/j.foreco.2005.03.029

3. Z. Bolat, N. S. Mukhamadiyev, N. Z. Ashikbaev, G. Z. Mengdibayeva, T. Gokturk, Forest pathology pattern of forest stands of the green belt of astana, OnLine Journal of Biological Sciences, 18, 158-161 (2018) doi 10.3844/ojbsci.2018.158.161 
4. K. Voolma, K. Hiiesaar, I. H. Williams, A. Ploomi, K. Jõgar, Cold hardiness in the preimaginal stages of the great web-spinning pine-sawfly, Acantholyda posticalis Agricultural and Forest Entomology, 18, 432-436 (2016) doi 10.1111/afe.12172

5. C. Bystrowski, Synchronization of population dynamics of pine foliophages on the example of the autumnal searches in the Ostrow Mazowiecka forest district in the years 1986-1997 Folia Forestalia Polonica, Series A 40, 95-106 (1998)

6. K. Voolma, E. Pilt, H. Ounap, The first reported outbreak of the great web-spinning pine-sawfly, Acantholyda posticalis (Mats.) (Hymenoptera, Pamphiliidae), in Estonia Forestry Studies 50, 115-122 (2009)

7. S.-J. Park, S.-G. Lee, S.-C. Shin, B.-Y. Lee, Y.-J. Ahn, Larvicidal and antifeeding activities of oriental medicinal plant extracts against four species of forest insect pests, Applied Entomology and Zoology, 32, 601-608 (1997) doi 10.1303/aez.32.601

8. L. A. Lacey, D. Grzywacz, D. I. Shapiro-Ilan, R. Frutos, M. Brownbridge, M. S. Goettel, Insect pathogens as biological control agents: Back to the future, Journal of Invertebrate Pathology, 132, 1-41 (2015) doi 10.1016/j.jip.2015.07.009

9. B. Głowacka, I. Skrzecz, C. Bystrowski, Reducing the abundance of great pine webspinning pine sawfly Acantholyda posticalis Mats. in pine stands Sylwan 158, 323-330 (2014)

10. P. Gatto, A. Zocca, A. Battisti, M. J. Barrento, M. Branco, M. R. Paiva, Economic assessment of managing processionary moth in pine forests: A case-study in Portugal, Journal of Environmental Management, 90, 683-691 (2009) doi 10.1016/j.jenvman.2008.01.007

11. K. Zhichkin, V. Nosov, L. Zhichkina, V. Zhenzebir, O. Sagina, Cadastral appraisal of lands: agricultural aspect, IOP Conference Series: Earth and Environmental Science, 421, 022066 (2020) doi: 10.1088/1755-1315/421/2/022066

12. A. M. S. Smith, et al., Remote sensing the vulnerability of vegetation in natural terrestrial ecosystems, Remote Sensing of Environment, 154, 322-337 (2014) doi 10.1016/j.rse.2014.03.038

13. C. D. Allen, et al., A global overview of drought and heat-induced tree mortality reveals emerging climate change risks for forests, Forest Ecology and Management, 259, 660-684 (2010) doi 10.1016/j.foreco.2009.09.001

14. I. Skrzecz, A. Perlinska, Current problems and tasks of forest protection in Poland Folia Forestalia Polonica, Series A 60, 161-172 (2018) doi 10.2478/ffp-2018-0016

15. V. R. Kane, et al., Assessing fire effects on forest spatial structure using a fusion of landsat and airborne LiDAR data in Yosemite national park, Remote Sensing of Environment, 151, 89-101 (2014) doi 10.1016/j.rse.2013.07.041

16. L. N. Zhichkina, V. V. Nosov, K. A. Zhichkin, H. T. Aydinov, V. N. Zhenzhebir, V. V. Kudryavtsev, Satellite monitoring systems in forestry, Journal of Physics: Conference Series, 1515, 032043 (2020) doi:10.1088/1742-6596/1515/3/032043

17. A. Lakomiak, K. A. Zhichkin, Photovoltaics in horticulture as an opportunity to reduce operating costs. A case study in Poland, Journal of Physics: Conference Series 1399, 044088 (2019) doi 10.1088/1742-6596/1399/4/044088

18. L. Gustafsson, et al., Retention forestry to maintain multifunctional forests: A world perspective BioScience 62, 633-645 (2012) doi 10.1525/bio.2012.62.7.6

19. C. A. Kolden, J. A. Lutz, C. H. Key, J. T. Kane, J. W. van Wagtendonk, Mapped versus actual burned area within wildfire perimeters: Characterizing the unburned, Forest Ecology and Management, 286, 38-47 (2012) doi 10.1016/j.foreco.2012.08.020 
20. K. A. Zhichkin, V. V. Nosov, V. I. Andreev, O. K. Kotar, L. N. Zhichkina, Damage modelling against non-targeted use of agricultural lands, IOP Conference Series: Earth and Environmental Science ,341, 012005 (2019) doi 10.1088/1755-1315/341/1/012005

21. J. S. Bale, S. A. L. Hayward, Insect overwintering in a changing climate, Journal of Experimental Biology, 213, 980-994 (2010) doi 10.1242/jeb.037911

22. N. Soltani, H. Lechekhab, G. Smagghe, Impact of the insect growth regulator diflubenzuron on biochemical composition of cuticle of the shrimp, Penaeus kerathurus Communications in agricultural and applied biological sciences, 74, 137141 (2009)

23. E. Rodríguez, Z. Gómez De Balugera, M. C. Sampedro, M. A. Goicolea, R. J. Barrio, Persistence of diflubenzuron on conifer forest foliage in a Mediterranean-climate ecosystem following aerial application International, Journal of Environmental Analytical Chemistry, 83, 433-442 (2003) doi 10.1080/0306731031000104722

24. V. Nosov, M. Tindova, K. Zhichkin, M. Mirgorodskaya, Application development for accidental pollution assessment on chemical manufacturers (pollution from chemical waste), IOP Conference Series: Earth and Environmental Science, 337, 012014 (2019) doi 10.1088/1755-1315/337/1/012014

25. L. Zhichkina, V. Nosov, K. Zhichkin, M. Mirgorodskaya, V. Avdotin, Impact of outof-service wells on soil condition, IOP Conference Series: Earth and Environmental Science, 421, 062021 (2020) doi 10.1088/1755-1315/421/6/062021 